\title{
Canadian Theses in Forestry and Related Subject Fields 1963-1967
}

Compiled by V. Timmer, B. Bradbury and G. F. Weetman from lists supplied by the Faculties of Forestry at the University of British Columbia, Laval, New Brunswick, and Toronto, and from the Annual Lists of Canadian Theses, prepared by the National Library of Canada, Ottawa for the years 1962/63, $1963 / 64,1964 / 65$, and 1965/66.

A previous listing covering the years $1913-1962$, was published in September 1962 issue of the Forestry Chronicle.

\section{ACADIA UNIVERSITY}

1965

(1) DEMONE, G. R. A study of forest regeneration following fire on Cape George, Antigonish County, Nova Scotia. M.Sc.

\section{UNIVERSITY OF ALBERTA} 1964

(2) DUGLE, J. M. R. A taxonomic study of western Canadian species in the genus Betula. Ph.D.

\section{UNIVERSITY OF BRITISH COLUMMBIA} 1963

(3) AHUJA, J. C. Statistical problems in the study of growth. Ph.D.

(4) CSIZMAZIA, J. The application of electronic computers in forestry, and forestry research. M.F.

(5) DHANJU, K. S. Effect of shear and transverse compression on deflection of beams in elastic range. MASc.

(6) HORVATH, O. Contributions to nesting ecology of forest birds. M.F.

(7) IFJU G. Influence of cellulose chain length on the mechanical behavior of Douglas fir wood in tension parallel to grain. Ph.D.

(8) JURAZS, P. E. Penetrability of a western red cedar stem. M.F.

(9) KOZAK, A. Analysis of some factors associated with distribution and intensity of attack by cone and seed insects in Douglas fir. Ph.D.

(10) PASZNER L. The influence of fibre chemical constituents in oil-tempering of hardboard. M.F

(11) SAFRANYIK, L. Analysis of some factors influencing the distribution and abundance of the poplar and willow borer (Sternochetus lapathi $(L)$ ) on Scouler Willow (Salix scouleriana Barratt). M.F.

(12) SMITH, R. B. Edaphic aspects of an ecological classification of the interior western hemlock dry subzone forests of British Columbia. Ph.D.

(13) STRACHAN, A. M. Benefit cost-analysis as a thought process applied to alternative uses of recreational resources in national parks, with special reference to Banff National Park, Canada, and Peak District National Park, England. M.A.
(14) TUSKO, F. F. A study of variability in certain Doug. las-fir populations in British Columbia. Ph.D.

(15) WALLIS, J. H. Precipitation of the Fraser River basin: a descriptive study. M.A.

1964

(16) BAILEY, G. R. Effect of competition on the growth and crown from of lodgepole pine. M.F.

(17) BELL, M. A. M. Phytocoenoses in the dry subzone of the interior western hemlock zone of British Colum bia. Ph.D.

(18) CLARK, R. N. Sales forecasting in the plywood in dustry. M.B.A

(19) CROWTHER, J. W. F. An investigation of the movement of British Columbia softwood lumber to United States markets. M.B.A

(20) HALEY, D. Past demand and future prospects for Canadian Douglas fir. M.F.

(21) HANCOCK, W. $V$. The influence of native fatty acids on the formation of glue bonds with heat-treated wood. Ph.D.

(22) HUDAK, J. Saprophytes in the stem of living, healthy Tsuga heterophylla (Raf.) Sarg. and their role in decay resistance of the wood. M.F.

(23) JABLANCZY, A. Influence of slash burning on the establishment and initial growth of seedlings of Douglas-fir, western hemlock and western red cedar. Ph.D.

(24) MURPHY, B.C. The grievance field: An empirical studv of grievance processes in a plywood factorv. M.A.

(25) NEWNHAM, R. M. The development of a stand model for Douglas fir. Ph.D.

(26) ORLOCI, L. Vegetational and environmental variations in the ecosystems of the coastal western hemlock zone. Ph.D.

(27) PALKA, L. C. Factors influencing the strength properties of Douglas fir plywood normal to glueline. M.F.

(28) PARKER, W. S. Outdoor recreation and the public interest: A study in land-use conflicts. M.A.

(29) PETERSON E. B. Plant associations in the subalpine mountain hemlock zone in southern British Columbia. Ph.D.

(30) SYDNEYSMITH, S. An application of linear programming to log allocation in the forest industry of British Columbia. M.A.

(31) SZIKLAI, O. Variation and inheritance of some physiological and morphological traits in Pseudotsuga menziesii (Mirb.) Franco var menziesii. Ph.D.

(32) WU, $Y$-t. Intra-increment lignin content of five western Canadian coniferous woods M.

1965

(33) BARR, B. M. Central Siberia - a new primary industrial region? MA

(34) FRANCIA, F. C. Studies of some aspects of behaviour in the ambrosia beetle Trypodendron lineatum (Olivier). Ph.D.

(35) GILMOUR, J. F. The forest industry as a determinant of settlement in British Columbia: The case for integration through regional planning. M.S. 
(36) HEGER, L. Morphogenesis of stems of Douglas fir (Pesudotsuga menziesii (Mirb.) Franco). Ph.D.

(37) JAKOY, A. G. Influence of chemical fertilizers on the survival and growth of planted Douglas fir in coastal British Columbia. M.F.

(38) KURAMOTO, R. T. Plant associations and succession in the vegetation of the sand dunes of Long Beach, Vancouver Island. M.Sc.

(39) McBEAN, R. P. Stress analysis of wood stave pipe. M.A.SC.

(40) McBRIDE, R. P. A microbiological control Melampsora medusae Thum. rust on Pseudotsuga menziesii (Mirb.) Franco seedlings. M.Sc.

(41) NAUTIYAL, J. C. A survey of economic implications of fast-growing tree plantations for Uttar Pradesh in India. M.F.

(42) RETFALVI, L. I. Breeding behaviour and feeding habits of the bald eagle (Haliaeetus leucocephalus L.) on San Juan Island, Washington. M.F.

(43) WADE, L. K. Vegetation and history of the sphagnum bogs of the Tofino Area, Vancouver Island. M.Sc.

(44) WANG, Y-m. Use of a series of aerial photographs to estimate growth of trees and stands. M.F.

1966

(45) BROOKE, R. C. Vegetation-environment relationships of subalpine mountain hemlock zone ecosystems. Ph.D.

(46) CHOW, S-z. Effect of resin impregnated core veneer on shear strength of Douglasfir plywood. M.F.

(47) DOBIE, J. Product yield and value, financial rotations and biological relationships of good site Douglas fir M.F.

(48) HALEY, D. An economic appraisal of sustained yield forest management for British Columbia. Ph.D.

(49) HOMOKY, I. G. J. Relationship of some coniferous wood strength properties to specific gravity variations within growth increments. M.F.

(50) MUIR, J. A. A study of epidemics of lodgepole pine dwarf mistletoe in Alberta. M.F.

(51) OSBORN, J. E. An analysis of the growth of young stands of western red cedar and associated species on the University of British Columbia Research Forest Haney, British Columbia. M.F.

(52) PASZNER, L. Curing of drying oil in wood fibre webs by gamma-irradiation. Ph.D.

(53) ROLLER, K. J. A study of the needle and cone tissue of alpine fir (Abies lasiocarpa (Hook.) Nutt). M.Sc.

(54) STANEK, W. K. L. Occurrence, growth, and relative value of lodgepole pine and Engelmann spruce in the interior of British Columbia. Ph.D.

(55) WOOD, W. F. J. The economic outlook for the woodpulp industry in British Columbia. M.B.A.

\section{7}

(56) BRAMHALL, G. Longitudinal permeability within Douglas-fir (Pseudotsuga menziesii (Mirb.) Franco) growth increments. M.Sc.

(57) CARROW, J. R. Some effects of host tree nutrition on establishment and survival of the balsam woolly aphid Adelges piceae (Ratz.) M.Sc.

(58) CHIAM, Y. C. The use of aerial photographs to distinguish between stocking and density of western hemlock stands on the University of British Columbia Research Forest, Haney, British Columbia. M.F.

(59) COTTELL, P. L. The influence of changing logging technology upon the economic accessibility of the forest. M.F.

(60) HEJJAS, J. Comparison of absolute and relative standard errors and estimates of tree volumes. M.F.

(61) JOHNSTONE, W. D. Analysis of biomass, biomass sampling methods, and weight scaling of lodgepole pine. M.F.

(62) KOWALL, R. C. Soils and soil capability classification for forestry of the Mission Tree farm. M.Sc.

(63) LEE, Y. Stand models for lodgepole pine and limits to their application. Ph.D.

(64) LOU, J-K. The effect of secondary compression on shear strength. M.A.Sc.

(65) MITCHELL, W. B. The water component of the industrial location problem: British Columbia's pulp and paper industry. M.A.

(66) MOECK, R. A. Electron microscopic studies of antennal sensilla in the ambrosia beetle Trypodendron lineatum (Olivier) (Scolytidae). M.Sc.

(67) MULLINS, K. D. Changes in location and structure in the forest industry of north central British Columbia: 1909-1966. M.A.
(68) NAUTIYAL, J. C. Possible contributions of timber production forestry to economic development. Ph.D.

(69) PENTLAND, C. D. Some interrelations of root-rotting Basidiomycetes and soil-inhabiting Fungi impecfecti. Ph.D.

(70) PFEIFFER, K. Analysis of methods of studying operational efficiency in forestry. M.F.

(71) ROGERS, I. H. Wood extractives: The structure and chemistry of some triterpenes isolated from the bark of sitka spruce (Picea sitchensis). Ph.D.

(72) SPANKIE, C. M. D. Space for outdoor recreation: Planning aspects for a national policy. M.A.

(73) SUN B.C-h. Energy dissipation in paper tearing as time-dependert phenomenon. M.Sc.

(74) YU, K. C. The friction sawing of wood. M.A.Sc.

\section{CARLETON UNIVERSITY}

1964

(75) HENRY, C. E. The agricultural rehabilitation and development programme and its implication for Nova Scotia. M.A.

\section{UNIVERSITY OF GUELPH \\ 1965}

(76) BHATT, G. C. Studies on the fungal flora of cedar forests. M.Sc.

\section{LAVAL UNIVERSITY}

1963

(77) CARRIER, D. Etude sur les matières humiques des principaux sols forestiers du Québec. M.Sc.F.

(79) PINEAU, M. Etude in vitro sur la minéralisation de l'azote organique dans les humus forestiers. M.Sc.

\section{4}

(80) BARRY, R. Règles de classification pour les sciages de pin de l'est du Canada. M.Sc.F.

(81) BLOUIN, J.-L. Etude des tremblaies du bas St-Laurent, M.Sc.F.

(82) KONG, K.-T. Etude sur le dosage du phosphore assimilable dans les sols forestiers. M.Sc.F.

(83) MICHON, L. Dispositif expérimental de contrôle dans les aires de coupes sélectives de Station II à Franquelin, comté de Saguenay. M.Sc.F.

\section{5}

(84) BLANCHET, B. Les associations végétales des cédrières des comtés de Kamouraska et de l'Islet. M.Sc.

(85) BROUSSEAU, J. Effects secondaires de l'absorption d'eau sur le bois: étude à teneur en humidité constante. M.Sc.

(86) GIGUERE, M. Etude de la carie et des défauts externes des arbres dans un peuplement de sapin (Dryopteris-Oxalis, 80 ans). M.Sc

(87) MILOT, F. Essai de cartographie forestière à l'aide de la photographie aérienne verticale. M.Sc

(88) RINFRET, R. Essai de planification des opérations forestières grâce à la photogrammétrie et à la recherche opérationnelle. M.Sc.

(89) VIETINGHOFF, A. Une analyse d'exploitation fores tière. M.Sc

(90) VILLENEUVE, P. Calcul de l'erreur d'échantillonnage et détermination de l'aire optimale des parcelleséchantíllons. M.Sc.

(91) BERTRAND, V. Etude de l'accroissement en diamètre et en volume du sapin baumier dans la Forêt Montmorency. M.Sc.

(92) BOLGHARI H. La réaction d'un peuplement dense de sapin baumier âgé de 40 ans à la suite d'une éclaircie au Québec. M.Sc.

(93) FRANCOEUR, A. La faune myrmécologique de l'érablière à sucre (Aceretum saccharophori, Dansereau) de la région de Québec. M.Sc.

(94) FRECHETTE, A. Etude sur les levés cadastraux dans la province de Québec avec considération spéciale des méthodes photogrammétriques. D. Photogrammétrie.

(95) GAGNON, P.-A. Application de nouvelles techniques de triangulation aérienne pour la cartographie à l'échelle de 1/5000. M.Sc. Photogrammétrie.

(96) MEYER, D. Influence des sols sur le succès des 
plantations de pin rouge (Pinus resinosa Ait.) dans la région de Québec. M.Sc.F.

(97) SCHLAEPPER, R. Estimation du volume sur pied d'un peuplement forestier à partir de photographies aériennes verticales à très grande échelle. M.Sc.F.

\section{7}

(98) DJOLANI, B. Mesure hygrométrique par capteurs du type Dunmore avec considération particulière des effets de second ordre de l'absorption d'humidité das le bois. M.Sc.F.

(99) DUMONT, J. M. Construction de tarifs de cubage à l'aide de modèles mathématiques et mesurage, en longueur d'arbre, des bois abattus. M.Sc.F

(100) FORTIN, J.-A. Le rôle des régulateurs de croissance dans la formation des mycorhizes ectotrophes. D.Sc. Ecologie.

(101) HARDY, Y. Tordeuse des bourgeons de l'épinette (Choristoneura fumiferana, Clem.) revue approfondie des travaux. M.Sc. Aménagement et sylviculture.

(102) OUELLET, F. Etude de l'effet d'entaille en traction chez les bois. D.S. Exploitation et Utilisation.

(103) RODRIGUE, J.-M. Cubage de tiges en P.M.P. à l'aide de modèles mathématiques. M.Sc. Sciences forestières.

\section{MCGILL UNIVERSITY}

1963

(104) LAVALLEE, A. Leucostoma canker of larch in Quebec. M.Sc.

(105) WALTHER, A. Forest ecological studies of the Monteregian Hills of southern Quebec. MSc.

1964

(106) BHATTACHARJEE, S. S. A study of pectic material from the bark of amabilis fir (Abies amabilis). Ph.D.

(107) BRYANT, D. G., Balsam woolly aphid, (Adelges piceae, Ratz), development on branches of balsam fir, (Abies balsamea (L) Mill) M.Sc.

(108) COTTON D. R The influence of soil characteristics and fertilizer treatment of growth and chemical composition of Pinus resinosa. M.Sc.

(109) LAMBERT, J. D. H. The ecology of terricolous lichens of the northern conifer-hardwood forests of central Canada. M.Sc.

1965

(110) MORTENSON, E. The relationship between growth of Picea glauca (Moench) Voss, Picea mariana (Mill) B.S.P. and summer temperatures in sub-arctic Canada. M.Sc.

(111) ROUSE, R. Aspects of a forest microclimate. Ph.D.

\section{6}

(112) ROBERGE, M., Urea metabolism in a black spruce humus. Ph.D.

\section{UNIVERSITY OF NEW BRUNSWICK}

1963

(113) BOYD, C. W. An appraisal of the Waterways EXperiment Station, Vicksburg, trafficability system, with particular reference to a forestry application. M.Sc.

(114) HENDERSON, C. S. The effect of frost on the shearing and splitting resistance of wood. M.Sc.

(115) PRICE, P. A study on the fecundity \& survival of Polygraphus rufipennis (Kirby) in black, red \& white spruce. M.Sc.

\section{5}

(116) BEANLANDS, E. E. The effects of bark moisture content on Polygraphus rufipennis (Kirby) adults and their developing broods. M.Sc.F.

(117) GRIFFIN, R. Method of taxing woodlands based on potential productivity. M.Sc.F.

(118) MATTHEWS, K. The form of site-index curves for aspen. M.Sc.F.

(119) OLIVER, F. Wheel slip in relation to vehicle speed on an uncompacted mineral soil under uncontrolled moisture conditions. M.Sc.F.

(120) SYKES, J. The silvicultural status of white pine (Pinus strobus L.) in New Brunswick. M.Sc.F.

(121) TAO, H. Gross merchantable tree-volume tables. M.Sc.F.

(122) HAZENBERG, G. An analysis of the New Brunswick lumber industry. M.Sc.F

(123) PRINS, G. A policy for the management of small forest holdings in New Brunswick, M.Sc.F.

\section{7}

(124) KETTELA, G. The cone and seed insects of balsam fir, Abies balsamea (L.) Mill. M.Sc.F.

(125) POST, J. The effect of intensity of radiation on height growth, weight increment, and maximum rate of photosynthesis, in mountain maple seedlings. M.Sc.F.

\section{QUEEN'S UNIVERSITY}

1963

(126) WEBBER, P. J. Vegetation gradients in swamp forests of eastern Ontario. M.Sc.

1966

(127) JAFRI, S. Forest composition in the Frontenac axis region, Ontario. M.Sc.

\section{SAINTE-ANNE UNIVERSITY}

1965

(128) DOUCET, J. L'industrie forestière chez les Acadiens de la Baie Ste-Marie de 1860 à 1930. M.A.

\section{UNIVERSITY OF SASKATCHEWAN}

1963

(129) NEWSOME, R. D. A phytosociological study of the woody, forest vegetation of the Cypress Hills. M.Sc.

1964

(130) MORRALL, R. A. A. An ecological study of soil microfungi of upland boreal forest at Candle Lake, Saskatchewan. M.A

(131) SWAN, J. M. A. A phytosociological study of upland boreal forest at Candle Lake, Saskatchewan. M.A.

1965

(132) SIDHU, S. S. Response of plant species to grazing in the forest region of Saskatchewan. M.Sc.

\section{UNIVERSITY OF TORONTO}

1963

(133) ANDREWS, P. J. An economic study of the particle board industry in Canada. M.Sc.F

(134) GERRARD, D. J. Tree volume estimation by weighted multiple regression. A comprehensive computer program. Volume I and Volume II, Appendix C. M.Sc.F.

(135) MICHALOWICZ, A. Z. Interregional comparison of the transportation costs of newsprint. M.Sc.F.

1964

(136) ACKERMAN, R. F. The effect of light and temperature on the germination of jack pine and lodgepole pine seeds. M.Sc.F. (Forestry).

(137) CHOPOWICK, R. E. A study of seed production in relation to the nutrition of red pine (Pinus resinosa Ait.). M.Sc.F

(138) LINZON, S. N. Studies on the nature and etiology of semi mature tissue needle blight of eastern white pine. Ph.D.

(139) MORRISON, I. K. The role of manganese in the survival and growth of seedlings of jack pine and spruce. M.Sc.F

(140) RICE, P. F. On the infection biology of Fomes annosus. M.Sc.F.

1965

(141) BELL, T. I. W. The effect of pretreatment on seedling survival and growth. M.Sc.F.

(142) BURGER D. Calcium release and weatherability of some primary minerals assessed with jack pine (Pinus banksiana Lamb) and weathering solutions. Ph.D.

(143) GLERUM, C. Effects of frost on some coniferous species. M.Sc.F.

(144) HOWARD, C. P. A comparative examination and case analysis of financial maturity in forestry. M.Sc.F.

145) ROY, R. M. Simulated fallout studies in conifers. M.A.

(146) SMITH, V. G. The construction of production standards for mechanical logging operations based on environmental factors. M.Sc.For.

(147) STEWARD, J. V. The demand and supply of white pine lumber, past, present and in the future. M.Sc.F. 
(148) BALATINECZ, J. J. The physiological mechanisms of earlywood-latewood differentiation in larch. Ph.D.

(149) BONNOR G. M. Predicting stem diameter distributions and yield for red pine plantations in Ontario. M.Sc.F.

(150) CHANG, C. I.-J. Specific gravity variation in plantation grown white spruce, M.Sc.F.

(151) CHENG, F. Radiation studies in conifers. M.A.

(152) FRANCIS, G. J. Optimum management intensity of forest land. M.Sc.F.

(153) KONDO, E. S. Host-parasite relationships in the Dutch elm disease. M.Sc.F

(154) NICHOLSON, J. J. M. Analysis of variation in wood properties of seedlings from controlled crosses of Douglas fir grown under two photoperiods. M.Sc.F.
(155) ANDERSON, H. W. Protection wood in sugar maple (Acer sarcharum Marsh). M.Sc.F.

(156) FAYLE, D. C. F. Patterns of radial growth in tree roots. Ph.D.

(157) INNES, M. R. An economic analysis of white spruce plantations in southern Ontario. M.Sc.F.

(158) KUMAR, P. A field study of infiltration on various soils. M.Sc.F.

(159) MORSINK, W. A. G. Municipal tree management in urban areas. M.Sc.F.

\section{UNIVERSITY OF WESTERN ONTARIO}

1966

(160) LEE, Y. H. Growth studies in the white ash (Fraxinus americana L.) M.Sc.

\section{AUTHORS' INDEX}

ACKERMAN, R. F 136

AHUJA, J. C.

ANDERSON, $\mathrm{H}, \mathrm{W} \quad 155$

ANDREWS, P. J. ........................ 133

BAILEY, G. R. 16

BALATINECZ, J. J 148

BARR, B. M. ............................ 33

BARRY, R.

BEANLANDS, E. E. ..................... 116

BELL, M. A. M. ..................... 17

BELL, T. I. W. .............................. 141

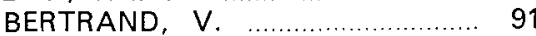

BHATT, G. C.

BHATTACHARJEE, S. S. ............. 106

BLANCHET, B. ........................... 84

BLOUIN, J.-L. ….......................... 81

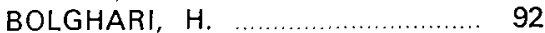

BONNOR, G. M. ....................... 149

BOYD, C. W. ............................... 113

BRAMHALL, G. ......................... 56

BROOKE, R. C. ......................... 45

BROSSEAU, J. ............................. 85

BRYANT, D. G. .......................... 107

BURGER，D. ................................. 142

CARRIER, D. ............................. 77

CARROW, J. R. ......................... 57

CHANG, C. I.-J. .......................... 150

CHARETTE， B. ............................. 78

CHENG, F. ............................... 151

CHIAM, Y. C. ............................. 58

CHOPOWICK, R. E. ..................... 137

CHOW, S-Z ….......................... 46

CLARK, R. N. ……........................... 18

COTTELL, P. L. ........................... 59

COTTON, D. R.

CROWTHER， J.W.F. ................... 19

CSIZMAZIA， J. ........................... 4

DEMONE, G. R

DHANJU, K. S. ........................... 5

DJOLANI, B. .................................. 98

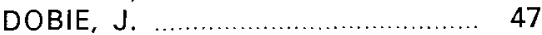

DOUCET, J. ..................................... 128

DUGLE, J. M. R.

DUMONT, J. M. .......................... 99

FAYLE, D. C. F. ............................. 156

FORTIN, J.-A. ................................ 100

FRANCIA， F. C. ............................. 34

FRANCIS, G. J. ........................... 152

FRANCOEUR, A. ........................... 93

FRECHETTE, A. ........................... 94

GAGNON, P.-A. ……................... 95

GERRARD, J. D. ............................. 134

GIGUERE, $M$.
GILMOUR, J. T.

GLERUM, C. .

GRIFFIN， R.

35

143

HALEY, D.

20,48

HANCOCK, W. V

21

HAZENBERG, G

122

HARDY, $Y$.

HEGER, L.

HEJJAS, J.

HENDERSON, C. S

HENRY, C. E.

HOMOKY, I. G. J

HORVATH, O.

HOWARD, C. P.

HUDAK, J.

101

36

60

114

75

49

6

IFJU, G.

22

INNES, M. R.

7

JABLANCZY, A. 157

JAFRI, S.

23

JAKOY A. G.

127

JURAZS, P. E.

KETTELA, G.

KONDO, E. S.

KONG, K-T

KOWALL, R. C.

KOZAK A

KUMAR, $P$

KURAMOTO, R. T.

LAMBERT, J. D. H.

LAVALLEE, A

LEE, Y.

LEE, Y. $\mathrm{H}$.

LINZON, S. N.

LOU, J-K.

N.

MATTHEWS, $K$.

MCBEAN, R. D.

MCBRIDE，R. P.

MEYER, D.

MICHALOWICZ, A. Z. ................ 135

MICHON, L.

MILOT, F.

MITCHELL, W. B.

MOECK, R. A.

MORRALL, R. A. A

MORRISON, I. K.

MORSINK, W. A. G.

MORTENSON, E.

MUIR, J. A.

MULLINS, K. D.

MURPHY, B. C.

NAUTIYAL, J. C.

NEWNHAM, R. M.

41,68
NEWSOME, R. D.

NICHOLSON, J. J. M.

129

OLIVER, F.

119

ORLOCI, L.

OSBORN, J. E.

OUELLET, F.

51

PALKA, L. C. 27

PARKER, W. S. ........................ 28

PASZNER, L. ........................ 10, 52

PENTLAND, C. D. ..................... 69

PETERSON, E. B. ......................... 29

PFEIFFER, K. $\quad 70$

PINEAU, M. ............................ 79

POST, J. ................................... 125

PRICE, P. ................................. 115

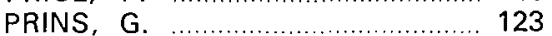

RETFALVI, L. I. .......................... 42

RICE, P. F. 140

RINFRET, $R$

ROBERGE, $M$

RODRIGUE, J-M

ROGERS, I. H.

ROLLER, K, J.

ROUSE, R.

ROY, R. M

88

112

103

71

53

111

147

SAFRANYIK, L.

11

SCHLAEPPER, R.

97

SIDHU, S. S.

SMITH, R. B.

SMITH, V. G.

SPANKIE, C. M. D

STANEK, W. K. L. ..................... 54

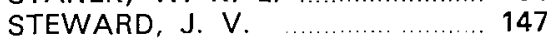

STRACHAN, A. M. ..................... 13

SUN, B.C-h. ............................... 73

SWAN, J.M. A. ...................... 131

SYDNEYSMITH， S. ................... 30

SYKES, J. .................................... 120

SZIKLAI, O. ............................... 31

TAO, H. 121

TUSKO, F. F.

VIETINGHOFF, A.

89

VILLENEUVE, $P$.

WADE, L. K.

WALLIS, J. H.

WALTHER, A.

43

WANG, $Y-m$.

WEBBER, $P, J$.

126

WOOD, W. F. J. ........................ 55

WU, Y-t.

YU. K. C. 